\title{
Effect of citrus waste on blood parameters of broiler birds with and without cocktail of enzymes
}

\author{
Devi Prasad Behera ${ }^{1}$, Amrit Pal Singh Sethi ${ }^{1}$, Chanchal Singh ${ }^{2}$, Udeybir Singh ${ }^{1}$ and Manju Wadhwa
}

1. Department of Animal Nutrition, Guru Angad Dev Veterinary and Animal Sciences University, Ludhiana, Punjab, India; 2. Department of Veterinary Biochemistry, Guru Angad Dev Veterinary and Animal Sciences University, Ludhiana, Punjab, India.

Corresponding author: Amrit Pal Singh Sethi, e-mail: apss_pau Idh@yahoo.co.in Co-authors: DPB: dr_devi_gadvasu@yahoo.com, CS: drchanchal833@gmail.com, US: udeybirchahal@gmail.com MW: mw7in@yahoo.co.in

Received: 24-10-2018, Accepted: 29-01-2019, Published online: 02-04-2019

doi: 10.14202/vetworld.2019.483-488 How to cite this article: Behera DP, Sethi APS, Singh C, Singh U, Wadhwa M (2019) Effect of citrus waste on blood parameters of broiler birds with and without cocktail of enzymes, Veterinary World, $12(4): 483-488$.

\begin{abstract}
Aim: This study aimed to assess the effect of different levels of citrus waste (CW) with or without enzyme cocktail on blood profile of broilers.

Materials and Methods: CW was sun-dried and grounded to powder CW. 256-day-old birds were distributed into eight groups; control (C), CW-supplemented diets $(2.5 \% \mathrm{CW}, 5.0 \% \mathrm{CW}$, and $7.5 \% \mathrm{CW})$, enzyme (E) cocktail supplemented diets (CE, 2.5\% CWE, 5.0\% CWE, and 7.5\% CWE). The diets were fed during starter (0-14 days), grower (15-21 days), and finisher (22-42 days) phases. Blood was collected from the wing vein from four birds per treatment. Serum was separated out after centrifugation and stored at $-20^{\circ} \mathrm{C}$ until further analysis. The samples were analyzed for liver function test (glucose, total protein [TP], albumin [ALB], and globulin), lipid profile (cholesterol and triglyceride), kidney function test (alanine aminotransferase, aspartate aminotransferase [AST], blood urea nitrogen [BUN], and creatinine), and antioxidant levels (catalase, superoxide dismutase [SOD], lipid peroxidation [LPx], glutathione peroxidase [GPx], glutathione [GSH], and Vitamins E and C).

Results: Blood profile data revealed that supplementation of CW showed no effect on TP, ALB, globulin, and BUN levels. Plasma cholesterol, triglyceride, and AST levels decreased linearly with an increase in the levels of CW in the diet. Catalase and SOD activity increased non-significantly with an increase in inclusion level of CW in the diets. LPx, GPx, and GSH activities decreased $(\mathrm{p} \leq 0.05)$ up to $5 \% \mathrm{CW}$-fed groups. Vitamin $\mathrm{E}$ and $\mathrm{C}$ activity were found to be highest $(\mathrm{p} \leq 0.05)$ in birds fed with diet supplemented with 5\% CW. GPx and GSH activities and serum Vitamin C levels were observed to be highest $(\mathrm{p}<0.05)$ in birds fed CW (at 5\%)-based diet supplemented with enzymes.
\end{abstract}

Conclusion: The blood profile showed that supplementation of $\mathrm{CW}$ up to $5 \%$ decreased cholesterol, triglyceride, and AST levels and improved the antioxidant status. Vitamin C levels were observed to be highest $(\mathrm{p}<0.05)$ in birds fed CW (at $5 \%$ )based diet supplemented with enzymes.

Keywords: antioxidant levels, citrus waste, cocktail of enzymes, lipid profile, liver and kidney function test.

\section{Introduction}

The exponential growth of broiler industry has raised the demand for feed and feed ingredients. Poultry industry requires 10.9 million MT of broiler feed to satisfy the nutritional requirement of the birds, in the poultry production system; feed alone costs about $60-70 \%$ of the total cost of production [1]. Increase in the prices and unpredictable availability of feed ingredients has a direct impact on the broiler industry. To meet the increased demand for feed, search for novel feed resources, particularly those not competing with human food, is a key for sustainable development of

Copyright: Behera, et al. Open Access. This article is distributed under the terms of the Creative Commons Attribution 4.0 International License (http://creativecommons.org/licenses/ by/4.0/), which permits unrestricted use, distribution, and reproduction in any medium, provided you give appropriate credit to the original author(s) and the source, provide a link to the Creative Commons license, and indicate if changes were made. The Creative Commons Public Domain Dedication waiver (http:// creativecommons.org/publicdomain/zero/1.0/) applies to the data made available in this article, unless otherwise stated. the poultry industry. The food processing sector generates approximately 1.81 million tonnes of fruit and vegetable wastes in India which are either composted or dumped in landfills or rivers, causing environmental hazards [2]. These wastes left after processing are rich in essential nutrients that have the potential to be used as feed supplement.

Citrus waste $(\mathrm{CW})$, a by-product of citrus processing industry, is available in huge quantities in India which includes $60-65 \%$ peel, $30-35 \%$ internal tissues, and up to $10 \%$ seeds which constitutes $50 \%$ of processed citrus [3]. The term citrus covers oranges, sweet lemon/lime, lemon, kinnow, grapefruit, tangerine, etc. The major by-products of processed citrus are dried pulp, molasses, washed pulp solids, and essential oils. Dried citrus pulp contains almost $5-10 \%$ crude protein, $6.2 \%$ ether extract, $10-40 \%$ soluble fiber (pectins), 54\% water-soluble sugars, 1-2\% calcium, and $0.1 \%$ phosphorus [2]. Besides, citrus pulp contains active antioxidants including a mix 
of flavonoids, isoflavones, flavones, anthocyanins, coumarins, lignans, catechins, and epicatechins [4]. Flavonoids have been reported to decrease the blood cholesterol and also quench the free radicals, thereby exerting antioxidant activity in laying hens [5]. It was found that utilization of dried citrus pulp up to $16 \%$ in diet significantly increased serum glucose and high-density lipoprotein and reduced cholesterol, low-density lipoprotein, and triglycerides in laying hens [6]. The use of CW will not only be a cost-effective alternative feed ingredient for economical broiler production but also will help in preventing environmental pollution and maintaining healthy blood profile of birds.

The present study was conducted to assess the impact of supplementation of $\mathrm{CW}$ on blood parameters of broiler birds without and with cocktail of enzymes.

\section{Materials and Methods}

\section{Ethical approval}

All procedures used in this study were approved by the Guru Angad Dev Veterinary and Animal Sciences University and Committee (IAEC-CPCSEA, New Delhi).

\section{CW procurement}

$\mathrm{CW}$ was procured from Punjab Agro Juices Ltd. (India). The material was sun-dried and grounded for further use. CW and other feed ingredients used were analyzed for proximate principles, phosphorus [7], and calcium content [8].

\section{Birds}

Broiler chicks were procured from Guru Angad Dev Veterinary and Animal Sciences University hatchery. 256-day-old birds were divided into eight groups (quadruplicate group of broiler chicks having eight birds in each replicate) and were fed diet control (C), 2.5\% CW, 5.0\% CW, 7.5\% CW, CE, 2.5\% CWE, $5.0 \% \mathrm{CWE}$, and $7.5 \% \mathrm{CWE}$. The cocktail of enzyme (E) had $\beta$-glucanase, xylanase, pectinase, cellulase, acid protease, natural protease, mannanase, $\alpha$-glucosidase, amylase, lipase, phytase, and $\alpha$-galactosidase. Eight experimental rations were formulated [9] for each phase, i.e., starter, grower, and finisher (up to $42^{\text {nd }}$ day) on deep litter system.

Environmental condition of house was optimum for rearing broilers, i.e., temperature was maintained at $85^{\circ} \mathrm{F}$ with relative humidity between $30 \%$ and $40 \%$. 24-h light was provided throughout the experimental period, i.e., light was hanged from ceiling at 7 feet above the ground level for proper lighting.

At the end of experiment, i.e. on the $42^{\text {nd }}$ day, blood was collected from the wing vein from four birds per treatment. Serum was separated out after centrifugation and stored at $-20^{\circ} \mathrm{C}$ until further analysis. Hemolysate was prepared from plasma-separated blood and stored at $-20^{\circ} \mathrm{C}$. The requisite stored samples were evaluated for liver function test (glucose, total protein [TP], albumin [ALB], and globulin), lipid profile (cholesterol and triglyceride), and kidney function test (alanine aminotransferase [ALT], aspartate aminotransferase [AST], blood urea nitrogen [BUN], and creatinine) by using Erba (Mannheim) kits. Antioxidant levels (catalase, superoxide dismutase [SOD], lipid peroxidation [LPx], glutathione peroxidase [GPx], glutathione [GSH], and Vitamins E and C) were analyzed using standard methods.

\section{Statistical analysis}

The collected data were analyzed using Statistical Package for the Social Sciences [10] at 95\% significant level using Duncan's level of significance values [11].

\section{Results}

\section{Effect of CW}

Supplementation of diet with CW, irrespective of supplementation of enzymes, showed no significant $(\mathrm{p} \leq 0.05)$ difference in glucose, TP, ALB, and globulin level (Table-1). However, the increased trend of blood glucose level was found with increased level of supplementation of diet with the highest glucose level $(293.74 \mathrm{mg} / \mathrm{dl})$ observed in $7.5 \% \mathrm{CW}$-supplemented diet and the lowest $(267 \mathrm{mg} / \mathrm{dl})$ was observed in control group.

Supplementation of diet with CW showed no difference in the cholesterol levels; however, the level decreased with an increase in the level of supplementation (Table-2), irrespective of enzyme supplementation. Supplementation of diet with CW, irrespective of supplementation of enzyme cocktail, decreased the plasma triglyceride levels of birds $(p \leq 0.05)$ at all levels of supplementation.

Creatinine levels and BUN were not affected by supplementation of $\mathrm{CW}$, irrespective of supplementation of enzyme cocktail (Table-3). Supplementation of diet with CW decreased $(\mathrm{p}<0.05)$ the activities of AST and ALT linearly, irrespective of supplementation of enzymes. The AST level varied $(\mathrm{p}<0.05)$ from 134.99 IU/L (diet supplemented with $7.5 \% \mathrm{CW}$ )

Table-1: Effect of feeding different levels of citrus waste on the blood parameters of broiler.

\begin{tabular}{lcccc}
\hline Citrus waste (\%) & Glucose $\mathbf{( m g / d l )}$ & TP $(\mathbf{g} / \mathbf{d l})$ & ALB $\mathbf{( g / d )}$ & Globulin $(\mathbf{g} / \mathbf{d l})$ \\
\hline 0 & 267.24 & 2.68 & 1.67 & 1.01 \\
2.50 & 272.86 & 2.62 & 1.72 & 0.90 \\
5.00 & 289.54 & 2.70 & 1.74 & 0.96 \\
7.50 & 293.74 & 2.74 & 1.72 & 1.02 \\
Pooled SEM & 14.053 & 0.114 & 0.077 & 0.085 \\
p-value & 0.602 & 0.705 & 0.711 & 0.520 \\
\hline
\end{tabular}

$\mathrm{TP}=$ Total protein, $\mathrm{ALB}=\mathrm{Albumin}, \mathrm{SEM}=$ Standard error of mean 
to $-165.4 \mathrm{IU} / \mathrm{L}$ (unsupplemented control diet), whereas ALT level varied $(\mathrm{p}<0.05)$ from $1.58 \mathrm{IU} / \mathrm{L}$ (birds fed diet supplemented with $5 \% \mathrm{CW}$ ) to $3.29 \mathrm{IU} / \mathrm{L}$ (birds fed unsupplemented control diet).

Antioxidant status revealed that supplementation of diet with $\mathrm{CW}$ improved $(\mathrm{p}<0.05)$ the activities of SOD and LPx and these activities increased linearly with an increase in the level of supplementation of $\mathrm{CW}$, irrespective of enzymes. The GPx, GSH, and Vitamins $\mathrm{C}$ and $\mathrm{E}$ were observed to be highest in birds fed diet supplemented with $\mathrm{CW}$ at $5 \%$, and further increase decreased these parameters. Catalase activity differed non-significantly (Table-4).

Table-2: Effect of feeding different levels of citrus waste on the lipid profile of blood in broiler.

\begin{tabular}{lcc}
\hline $\begin{array}{l}\text { Citrus } \\
\text { waste }(\%)\end{array}$ & $\begin{array}{c}\text { Cholesterol } \\
(\mathbf{m g} / \mathbf{d l})\end{array}$ & $\begin{array}{c}\text { Triglyceride } \\
(\mathbf{m g} / \mathbf{d l})\end{array}$ \\
\hline 0 & 109.70 & $96.66^{\mathrm{a}}$ \\
2.50 & 102.70 & $72.73^{\mathrm{ab}}$ \\
5.00 & 98.63 & $64.08^{\mathrm{ab}}$ \\
7.50 & 91.73 & $55.02^{\mathrm{b}}$ \\
Pooled SEM & 6.647 & 11.737 \\
p-value & 0.509 & 0.041 \\
\hline
\end{tabular}

a,b Means bearing different superscripts in a column differ significantly $(p \leq 0.05)$. SEM $=$ Standard error of mean

Table -3: Effect of feeding different levels of citrus waste on the liver and kidney function tests in broiler.

\begin{tabular}{lcccc}
\hline $\begin{array}{l}\text { Citrus } \\
\text { waste }(\%)\end{array}$ & $\begin{array}{c}\text { BUN } \\
(\mathbf{m g} / \mathbf{d l})\end{array}$ & $\begin{array}{c}\text { Creatinine } \\
(\mathbf{m g} / \mathbf{d l})\end{array}$ & $\begin{array}{c}\text { AST } \\
(\mathbf{I U} / \mathbf{L})\end{array}$ & $\begin{array}{c}\text { ALT } \\
(\mathbf{I U} / \mathbf{L})\end{array}$ \\
\hline 0 & 3.18 & 0.37 & $165.74^{\mathrm{a}}$ & $3.29^{\mathrm{a}}$ \\
2.50 & 3.91 & 0.36 & $148.20^{\mathrm{ab}}$ & $2.22^{\mathrm{ab}}$ \\
5.00 & 3.34 & 0.56 & $144.57^{\mathrm{b}}$ & $1.58^{\mathrm{b}}$ \\
7.50 & 3.33 & 0.47 & $134.99^{\mathrm{b}}$ & $1.83^{\mathrm{b}}$ \\
Pooled SEM & 0.43 & 0.096 & 6.127 & 0.454 \\
p-value & 0.610 & 0.703 & 0.025 & 0.038 \\
\hline
\end{tabular}

$\mathrm{a}, \mathrm{b}$ Means bearing different superscripts in a column differ significantly $(p \leq 0.05)$. BUN=Blood urea nitrogen, $\mathrm{ALT}=$ Alanine aminotransferase, $\mathrm{AST}=$ Aspartate aminotransferase, SEM=Standard error of mean

\section{Effect of enzymes}

Supplementation of CW-based diet with enzymes showed no significant difference in glucose, BUN, creatinine, TP, ALB, globulin, ALT, catalase activity, SOD activity, LPx activity, and GPx activity in blood, irrespective of levels of supplementation of $\mathrm{CW}$ in diet. However, triglyceride and cholesterol levels were higher $(\mathrm{p} \leq 0.05)$ in bird fed CW-based diet supplemented with enzymes in comparison to unsupplemented diet (Tables-5-8). Supplementation of CW-based diet with enzymes decreased $(\mathrm{p}<0.05)$ AST levels and ALT levels ( $>0.05)$. GSH activity and Vitamin $\mathrm{C}$ in blood were observed in birds fed CW-based diet supplemented with enzymes; however, Vitamin E levels decreased on supplementation of enzymes.

\section{CW $\times$ enzyme}

Data were analyzed to see the interactions between levels of supplementation of CW and inclusion of enzymes in CW-based diet, and the results revealed that TP varied $(\mathrm{p}<0.05)$ from $2.16 \mathrm{~g} / \mathrm{dl}$ (birds fed diet supplemented with $\mathrm{CW}$ at $2.5 \%$ ) to $3.09 \mathrm{~g} / \mathrm{dl}$ (birds fed diet supplemented with $\mathrm{CW}$ at $2.5 \%$ and enzymes). Serum albumin and globulin followed the trend of TP (Table-9). Supplementation of CW-based diet with enzymes decreased $(p<0.05)$ blood cholesterol levels, whereas the serum TG levels increased when CW-based diet was supplemented with enzymes (Table-10). Supplementation of diet with CW decreased $(p<0.05)$ AST and addition of enzymes to $\mathrm{CW}$-based diet further lowered $(\mathrm{p}<0.05)$ the AST activity. A similar trend was observed for ALT (Table-11).

Data on antioxidant status revealed that LPx activity varied from $309 \mathrm{nmol} / \mathrm{gHb}$ (birds fed diet supplemented with $5 \% \mathrm{CW}$ ) to $425 \mathrm{nmol} / \mathrm{gHb}$ (birds fed $\mathrm{CW}$ [at 7.5\%]-based diet supplemented with enzymes). GPx and GSH activities and serum Vitamin C levels were observed to be highest $(\mathrm{p}<0.05)$ in birds fed CW (at 5\%)-based diet supplemented with enzymes (Table-12). Birds fed diet supplemented with CW at

Table-4: Effect of feeding different levels of citrus waste on the antioxidant status of blood in broiler.

\begin{tabular}{|c|c|c|c|c|c|c|c|}
\hline $\begin{array}{l}\text { Citrus } \\
\text { Waste (\%) }\end{array}$ & $\begin{array}{c}\text { CAT } \\
(\mathrm{U} / \mathrm{gHb})\end{array}$ & $\begin{array}{c}\text { SOD } \\
(\mathrm{U} / \mathrm{mgHb})\end{array}$ & $\begin{array}{c}\text { LPX } \\
(\mathrm{nmol} / \mathrm{gHb})\end{array}$ & $\begin{array}{c}\text { GPX } \\
(\mathbf{U} / \mathrm{g} \mathrm{Hb})\end{array}$ & $\begin{array}{c}\text { GSH } \\
(\mu \mathrm{g} / \mathrm{ml})\end{array}$ & $\begin{array}{l}\text { Vitamin E } \\
(\mu \mathrm{mol} / \mathrm{L})\end{array}$ & $\begin{array}{c}\text { Vitamin C } \\
(\mathrm{mg} / \mathrm{dl})\end{array}$ \\
\hline 0 & 0.10 & $18.48^{\mathrm{b}}$ & $365.50^{\mathrm{ab}}$ & $35.40^{b}$ & $8.18^{b}$ & $0.17^{\mathrm{ab}}$ & $1.15^{\mathrm{b}}$ \\
\hline 2.50 & 0.09 & $22.82^{\mathrm{ab}}$ & $348.50^{\mathrm{b}}$ & $67.89^{\mathrm{ab}}$ & $10.91^{\mathrm{ab}}$ & $0.12^{b}$ & $1.09^{\mathrm{b}}$ \\
\hline 5.00 & 0.11 & $23.91^{\mathrm{ab}}$ & $329.50^{\mathrm{b}}$ & $108.14^{a}$ & $14.64^{a}$ & $0.29^{a}$ & $1.76^{\mathrm{a}}$ \\
\hline 7.50 & 0.14 & $32.61^{a}$ & $395.00^{\mathrm{a}}$ & $40.72^{b}$ & $11.82^{\mathrm{ab}}$ & $0.19^{a b}$ & $1.32^{\mathrm{ab}}$ \\
\hline Pooled SEM & 0.043 & 3.578 & 12.375 & 15.975 & 1.597 & 0.044 & 0.149 \\
\hline $\mathrm{p}$-value & 0.711 & 0.021 & 0.011 & 0.034 & 0.042 & 0.046 & 0.013 \\
\hline
\end{tabular}

$a, b$ Means bearing different superscripts in a column differ significantly $(p \leq 0.05)$. CAT $=$ Catalase, SOD $=$ Superoxide dismutase, $\mathrm{LPx}=$ Lipid peroxidation, $\mathrm{GPx}=$ Glutathione peroxidase, $\mathrm{GSH}=$ Glutathione

Table-5: Effect of feeding different levels of enzymes on the blood parameters of broiler.

\begin{tabular}{lcccc}
\hline Enzymes (g/q) & Glucose $(\mathbf{m g} / \mathbf{d l})$ & TP $(\mathbf{g} / \mathbf{d} \mathbf{l})$ & ALB $(\mathbf{g} / \mathbf{d l})$ & Globulin $(\mathbf{g} / \mathbf{d l})$ \\
\hline 0 & 279.57 & 2.58 & 1.64 & 0.94 \\
100 & 282.11 & 2.80 & 1.79 & 1.01 \\
Pooled SEM & 9.937 & 0.081 & 0.054 & 0.06 \\
p-value & 0.806 & 0.809 & 0.708 & 0.725 \\
\hline
\end{tabular}

$\mathrm{TP}=$ Total protein, $\mathrm{SEM}=$ Standard error of mean 
$5 \%$ had the highest $(\mathrm{p}<0.05)$ levels of Vitamin $\mathrm{E}$, and the addition of enzymes in CW-based diets decreased

Table 6: Effect of feeding different levels of enzymes on the lipid profile of blood in broiler.

\begin{tabular}{lcc}
\hline $\begin{array}{l}\text { Enzymes } \\
(\mathbf{g} / \mathbf{q})\end{array}$ & $\begin{array}{c}\text { Cholesterol } \\
(\mathbf{m g} / \mathbf{d l})\end{array}$ & $\begin{array}{c}\text { Triglyceride } \\
(\mathbf{m g} / \mathbf{d l})\end{array}$ \\
\hline 0 & $91.68^{\mathrm{b}}$ & $58.10^{\mathrm{b}}$ \\
100 & $109.70^{\mathrm{a}}$ & $86.15^{\mathrm{a}}$ \\
Pooled SEM & 4.70 & 8.299 \\
p-value & 0.032 & 0.040 \\
\hline
\end{tabular}

$a, b$ Means bearing different superscripts in a column differ significantly $(p \leq 0.05)$. SEM = Standard error of mean
Vitamin E levels in blood. However, the catalase and SOD activities showed no significant difference between the groups.

\section{Discussion}

\section{Effect of CW}

Citrus pulp supplementation at the level of $6 \%$ in broiler ration did not show any negative effect on blood glucose level [12]. TP, ALB, and globulin did not vary significantly and were found within normal range [13]. It was also reported that inclusion of orange peel extract (OPE) and lemon peel extract (LPE) did not influence TP, ALB, and globulin [14]

Table-7: Effect of feeding different levels of citrus waste on the liver and kidney function tests in broiler.

\begin{tabular}{lcccc}
\hline Enzymes (g/q) & BUN (mg/d) & Creatinine $(\mathbf{m g} / \mathbf{d l})$ & AST (IU/L) & ALT (IU/L) \\
\hline 0 & 3.67 & 0.48 & $156.90^{\mathrm{a}}$ & 2.50 \\
100 & 3.21 & 0.41 & $139.81^{\mathrm{b}}$ & 1.96 \\
Pooled SEM & 0.304 & 0.068 & 4.333 & 0.321 \\
p-value & 0.520 & 0.562 & 0.021 & 0.504 \\
\hline
\end{tabular}

$a, b$ Means bearing different superscripts in a column differ significantly $(p \leq 0.05)$. BUN=Blood urea nitrogen, $A L T=A l a n i n e$ aminotransferase, AST=Aspartate aminotransferase, SEM=Standard error of mean

Table-8: Effect of feeding different levels of enzymes on the antioxidant status of blood in broiler.

\begin{tabular}{|c|c|c|c|c|c|c|c|}
\hline $\begin{array}{l}\text { Enzymes } \\
(g / q)\end{array}$ & $\begin{array}{c}\text { CAT } \\
(\mathrm{U} / \mathrm{gHb})\end{array}$ & $\begin{array}{c}\text { SOD } \\
(\mathrm{U} / \mathrm{mgHb})\end{array}$ & $\begin{array}{c}\text { LPx } \\
(\mathrm{nmol} / \mathrm{gHb})\end{array}$ & $\begin{array}{c}\text { GPx } \\
(\mathbf{U} / \mathbf{g ~ H b})\end{array}$ & $\begin{array}{c}\text { GSH } \\
(\mu \mathrm{g} / \mathrm{ml})\end{array}$ & $\begin{array}{l}\text { Vitamin E } \\
(\mu \mathrm{mol} / \mathrm{L})\end{array}$ & $\begin{array}{c}\text { Vitamin C } \\
(\mathrm{mg} / \mathrm{dl})\end{array}$ \\
\hline 0 & 0.07 & 23.37 & 352.25 & 59.06 & $9.49^{b}$ & $0.26^{a}$ & $0.45^{b}$ \\
\hline 100 & 0.15 & 25.54 & 367.00 & 67.01 & $13.29^{a}$ & $0.13^{b}$ & $2.22^{\mathrm{a}}$ \\
\hline Pooled SEM & 0.03 & 2.53 & 8.751 & 11.296 & 1.13 & 0.031 & 0.105 \\
\hline p-value & 0.801 & 0.705 & 0.607 & 0.708 & 0.045 & 0.012 & 0.023 \\
\hline
\end{tabular}

a,bMeans bearing different superscripts in a column differ significantly $(p \leq 0.05)$. CAT=Catalase, SOD $=$ Superoxide dismutase, $\mathrm{LPX}=$ Lipid peroxidation, $\mathrm{GPx}=$ Glutathione peroxidase, $\mathrm{GSH}=$ Glutathione, $\mathrm{SEM}=\mathrm{Standard}$ error of mean

Table-9: Effect of citrus wastexenzyme on the blood parameters of broiler.

\begin{tabular}{lcccccc}
\hline Treatments & Citrus (\%) & Enzymes $(\mathbf{g} / \mathbf{q})$ & Glucose $(\mathbf{m g} / \mathbf{d l})$ & TP $(\mathbf{g} / \mathbf{d l})$ & ALB $(\mathbf{g} / \mathbf{d l})$ & Globulin $(\mathbf{g} / \mathbf{d l})$ \\
\hline C & 0 & 0 & 269.56 & $2.75^{\mathrm{a}}$ & $1.68^{\mathrm{ab}}$ & $1.07^{\mathrm{a}}$ \\
CW & 2.50 & 0 & 288.26 & $2.16^{\mathrm{b}}$ & $1.54^{\mathrm{b}}$ & $0.62^{\mathrm{b}}$ \\
CW & 5.00 & 0 & 258.08 & $2.69^{\mathrm{a}}$ & $1.67^{\mathrm{ab}}$ & $1.01^{\mathrm{a}}$ \\
CW & 7.50 & 0 & 302.39 & $2.72^{\mathrm{a}}$ & $1.67^{\mathrm{ab}}$ & $1.05^{\mathrm{a}}$ \\
CE & 0.00 & 100 & 264.91 & $2.62^{\mathrm{ab}}$ & $1.66^{\mathrm{ab}}$ & $0.95^{\mathrm{ab}}$ \\
CWE & 2.50 & 100 & 299.22 & $3.09^{\mathrm{a}}$ & $1.91^{\mathrm{a}}$ & $1.18^{\mathrm{a}}$ \\
CWE & 5.00 & 100 & 287.63 & $2.72^{\mathrm{a}}$ & $1.82^{\mathrm{ab}}$ & $0.90^{\mathrm{ab}}$ \\
CWE & 7.50 & 100 & 276.69 & $2.76^{\mathrm{a}}$ & $1.76^{\mathrm{ab}}$ & $1.00^{\mathrm{a}}$ \\
Pooled SEM & & & 19.874 & 0.162 & 0.108 & 0.12 \\
p-value & & & 0.602 & 0.042 & 0.031 & 0.011 \\
\hline
\end{tabular}

$a, b$ Means bearing different superscripts in a column differ significant $(p \leq 0.05)$. TP=Total protein, ALB=Albumin, $\mathrm{SEM}=$ Standard error of mean

Table-10: Effect of citrus wastexenzyme on the lipid profile of blood in broiler.

\begin{tabular}{lcccc}
\hline Treatment & Citrus waste (\%) & Enzymes $(\mathbf{g} / \mathbf{q})$ & Cholesterol $\mathbf{( m g / d )}$ & Triglyceride $(\mathbf{m g} / \mathbf{d l})$ \\
\hline C & 0 & 0 & $119.45^{\mathrm{a}}$ & $65.56^{\mathrm{b}}$ \\
CW & 2.50 & 0 & $114.28^{\mathrm{b}}$ & $62.94^{\mathrm{b}}$ \\
CW & 5.00 & 0 & $106.40^{\mathrm{b}}$ & $60.94^{\mathrm{b}}$ \\
CW & 7.50 & 0 & $98.68^{\mathrm{b}}$ & $42.96^{\mathrm{c}}$ \\
CE & 0.00 & 100 & $105.13^{\mathrm{b}}$ & $127.76^{\mathrm{a}}$ \\
CWE & 2.50 & 100 & $90.85^{\mathrm{b}}$ & $84.52^{\mathrm{a}}$ \\
CWE & 5.00 & 100 & $85.95^{\mathrm{b}}$ & $67.09^{\mathrm{b}}$ \\
CWE & 7.50 & 100 & $84.78^{\mathrm{b}}$ & $65.23^{\mathrm{b}}$ \\
Pooled SEM & & & 9.40 & 16.598 \\
p-value & & & 0.021 & 0.045 \\
\hline
\end{tabular}

a,bMeans bearing different superscripts in a column differ significantly $(p \leq 0.05)$. SEM=Standard error of mean 
Table-11: Effect of citrus waste $x$ enzyme on the liver and kidney function tests in broiler.

\begin{tabular}{lcccccc}
\hline Treatment & Citrus waste (\%) & Enzyme (g/d) & BUN (mg/dI) & Creatinine (mg/d) & AST (IU/L) & ALT (IU/L) \\
\hline C & 0 & 0 & 3.35 & 0.37 & $182.60^{\mathrm{a}}$ & $3.16^{\mathrm{a}}$ \\
CW & 2.50 & 0 & 4.33 & 0.35 & $160.08^{\mathrm{b}}$ & $2.39^{\mathrm{b}}$ \\
CW & 5.00 & 0 & 4.18 & 0.78 & $154.05^{\mathrm{bc}}$ & $2.37^{\mathrm{b}}$ \\
CW & 7.50 & 0 & 2.83 & 0.41 & $130.87^{\mathrm{c}}$ & $2.08^{\mathrm{b}}$ \\
CE & 0 & 100 & 3.00 & 0.37 & $148.89^{\mathrm{bc}}$ & $3.43^{\mathrm{a}}$ \\
CWE & 2.50 & 100 & 3.50 & 0.38 & $138.95^{\mathrm{bc}}$ & $2.37^{\mathrm{b}}$ \\
CWE & 5.00 & 100 & 2.50 & 0.35 & $136.33^{\mathrm{bc}}$ & $1.30^{\mathrm{c}}$ \\
CWE & 7.50 & 100 & 3.83 & 0.53 & $135.09^{\mathrm{bc}}$ & $0.77^{\mathrm{d}}$ \\
Pooled SEM & & & 0.609 & 0.135 & 8.665 & 0.642 \\
p-value & & & 0.804 & 0.807 & 0.011 & 0.031 \\
\hline
\end{tabular}

$a, b$ Means bearing different superscripts in a column differ significantly $(p \leq 0.05)$. BUN=Blood urea nitrogen, ALT=Alanine aminotransferase, AST=Aspartate aminotransferase, SEM=Standard error of mean

Table-12: Effect of citrus waste $\times$ enzyme on the antioxidant status of blood in broiler.

\begin{tabular}{|c|c|c|c|c|c|c|c|c|c|}
\hline Treatment & $\begin{array}{c}\text { Citrus } \\
\text { waste }(\%)\end{array}$ & $\begin{array}{c}\text { Enzyme } \\
(\mathrm{g} / \mathrm{dl})\end{array}$ & $\begin{array}{c}\text { CAT } \\
(\mathrm{U} / \mathrm{gHb})\end{array}$ & $\begin{array}{c}\text { SOD } \\
\text { (U/mgHb) }\end{array}$ & $\begin{array}{c}\text { LPx } \\
(\mathrm{nmol} / \mathrm{gHb})\end{array}$ & $\begin{array}{c}\text { GPX } \\
(\mathrm{U} / \mathrm{g} \mathrm{Hb})\end{array}$ & $\begin{array}{c}\text { GSH } \\
(\mu \mathrm{g} / \mathrm{ml})\end{array}$ & $\begin{array}{l}\text { Vitamin E } \\
(\mu \mathrm{mol} / \mathrm{L})\end{array}$ & $\begin{array}{c}\text { Vitamin C } \\
(\mathrm{mg} / \mathrm{dl})\end{array}$ \\
\hline C & 0 & 0 & 0.04 & 19.57 & $392.00^{\mathrm{ab}}$ & $33.67^{c}$ & $9.29^{b c}$ & $0.19^{\mathrm{bc}}$ & $0.31^{c}$ \\
\hline $\mathrm{CW}$ & 2.50 & 0 & 0.05 & 17.39 & $343.00^{\mathrm{b}}$ & $77.27^{b}$ & $9.37^{b c}$ & $0.08^{c}$ & $0.42^{c}$ \\
\hline CW & 5.00 & 0 & 0.09 & 23.91 & $309.00^{c}$ & $96.98^{\mathrm{a}}$ & $10.02^{\mathrm{bc}}$ & $0.44^{a}$ & $0.58^{c}$ \\
\hline CW & 7.50 & 0 & 0.10 & 32.61 & $365.00^{\mathrm{b}}$ & $28.32^{c}$ & $9.25^{b c}$ & $0.33^{\mathrm{ab}}$ & $0.48^{c}$ \\
\hline CE & 0.00 & 100 & 0.08 & 17.39 & $339.00^{\mathrm{b}}$ & $37.12^{c}$ & $7.07^{c}$ & $0.15^{\mathrm{bc}}$ & $1.87^{\mathrm{b}}$ \\
\hline CWE & 2.50 & 100 & 0.16 & 23.91 & $354.00^{\mathrm{b}}$ & $58.50^{\mathrm{b}}$ & $12.45^{\mathrm{b}}$ & $0.15^{\mathrm{bc}}$ & $1.89^{\beta}$ \\
\hline CWE & 5.00 & 100 & 0.18 & 28.26 & $350.00^{\mathrm{b}}$ & $119.30^{\mathrm{a}}$ & $20.03^{a}$ & $0.14^{\mathrm{bc}}$ & $2.94^{a}$ \\
\hline CWE & 7.50 & 100 & 0.18 & 32.61 & $425.00^{\mathrm{a}}$ & $53.12^{\mathrm{b}}$ & $13.62^{\mathrm{b}}$ & $0.06^{c}$ & $2.16^{\mathrm{b}}$ \\
\hline Pooled SEM & & & 0.061 & 5.06 & 17.501 & 22.592 & 2.259 & 0.063 & 0.211 \\
\hline$p$-value & & & 0.708 & 0.809 & 0.021 & 0.011 & 0.039 & 0.044 & 0.038 \\
\hline
\end{tabular}

$a, b, c$ Means bearing different superscripts in a column differ significantly $(p \leq 0.05)$. SOD=Superoxide dismutase, LPx $=$ Lipid peroxidation, GPx=Glutathione peroxidase, GSH=Glutathione, $\mathrm{SEM}=$ Standard error of mean

in blood. The cholesterol and triglyceride levels of blood decreased $(\mathrm{p} \leq 0.05)$ with an increase in the levels of CW in the diet [6,15-17]. The reduced cholesterol level of the blood could have been contributed by the pectin present in the citrus. It has been reported that pectin reduced pancreas enzyme activity, which resulted in increased fecal fat excretion [18] and lower fat deposition. ALT, AST, BUN, and creatinine levels were found to be in normal range [13] indicating normal functioning of the liver and kidney. It was also found that inclusion of higher levels of LPE, OPE, and Curcuma xanthorrhiza essential oil reduced the AST activity $(p \leq 0.05)$ without having any effect on BUN and creatinine level of blood [14]. The antoxidant levels i.e. SOD, catalase and GPx in the broiler blood increased with increase in levels of $\mathrm{CW}$ in the feed [19]. Supplementation of diet with LPE resulted in higher level of GPx activity $(\mathrm{p} \leq 0.05)$ in birds [14].

\section{Effect of enzymes}

It was found that there was a decrease in the level of blood cholesterol and triglyceride levels of blood $(p \leq 0.05)$ where orange waste without and with enzymes fed to chicken [15]. Lower cholesterol and triglyceride levels in the blood could be due to the presence of hesperidin in the $\mathrm{CW}$.

\section{CW $\times$ enzyme}

Supplementation of diet with dried lemon pulp in broiler ration showed no significant difference in the glucose, TP, ALB, and globulin level of the blood [4].
Citrus pulp supplemented at the level of $6 \%$ in broiler ration showed lowest blood cholesterol and triglyceride level [12]. Diet supplemented with sweet orange and other citrus fruits to broilers was efficient in lowering lipid profile of the blood [20,21]. It has been observed that increased level of $\mathrm{CW}$ in the broiler diet increased blood antioxidant status [19]. Citrus by-products are good source of Vitamin C [16] and contain substance showing antioxidant activity that is attributable to the flavones, i.e., hesperidins.

\section{Conclusion}

The blood profile showed that supplementation of $\mathrm{CW}$ up to $5 \%$ decreased cholesterol, triglyceride, and AST levels and improved the antioxidant status without affecting TP, ALB, globulin, and BUN levels. Vitamin C levels were observed to be highest $(p<0.05)$ in birds fed CW (at 5\%)-based diet supplemented with enzymes.

\section{Authors' Contributions}

DPB conducted the experiment and wrote the manuscript. CS helped in processing of samples in Veterinary Biochemistry Laboratory. APSS helped in statistical analysis of the results obtained. APSS and US helped in nutritional and managemental aspect of this study. MW helped in planning and execution of the work. All authors contributed in drafting the manuscript. All authors corrected the manuscript and read and approved the final manuscript. 


\section{Acknowledgments}

The authors are thankful to Rashtriya Krishi Vikas Yojana (CVU/B-1/17/12798-12812 dated 31.3.17) and Guru Angad Dev Veterinary and Animal Sciences University, Ludhiana, Punjab, India for providing all types of facilities to carry out the study. We also express our appreciation toward the staffs of Veterinary Biochemistry and Animal Nutrition Laboratory for their help in carrying out this study.

\section{Competing Interests}

The authors declare that they have no competing interests.

\section{Publisher's Note}

Veterinary World remains neutral with regard to jurisdictional claims in published institutional affiliation.

\section{References}

1. Thirumalaisamy, G., Muralidharan, J., Senthilkumar, S., Hema, S.R. and Priyadharsini, M. (2016) Cost-effective feeding of poultry. Int. J. Sci. Environ. Technol., 5(6): 3997-4005.

2. Wadhwa, M. and Bakshi, M.P.S. (2013) Utilization of Fruit and Vegetable Wastes as Livestock Feed and as Substrates for Generation of Other Value-Added Products. $1^{\text {st }}$ ed. RAP Publication, Bangkok, Thailand.

3. Crawshaw, R. (2004) Co-Product Feeds: Animal Feeds from the Food and Drinks Industries. Nottingham University Press, Nottingham.

4. Nobakht, A. (2013) Effects of different levels of dried lemon (Citrus aurantifulia) pulp on performance, carcass traits, blood biochemical and immunity parameters of broilers. Iran. J. Appl. Anim. Sci., 3(1): 145-151.

5. Iskender, H., Yenice, G., Dokumacioglu, E., Kaynar, O., Hayirli, A. and Kaya, A. (2016) The effects of dietary flavonoid supplementation on the antioxidant status of laying hens. Braz. J. Poult. Sci., 18(4): 663-668.

6. Nazok, A., Rezaei, M. and Sayyahzadeh, H. (2010) Effect of different levels of dried citrus pulp on performance, egg quality, and blood parameters of laying hens in early phase of production. Trop. Anim. Health. Prod., 42(4): 737-742.

7. AOAC. (2000) Official Methods of Analysis. $16^{\text {th }}$ ed. Association of Official Analytical Chemist, Washington, DC.

8. Talapatra, S.K., Roy, S.C. and Sen, K.C. (1940) Estimation of phosphorus, chlorine, calcium, sodium and potassium in foodstuffs. Ind. J. Vet. Sci. Anim. Husbandry, 10: 243-258.

9. ICAR. (2013) Nutrient Requirement of Animals Poultry (ICAR-NIANP). $3^{\text {rd }}$ ed. Krishi Bhawan, New Delhi.

10. SPSS. (2016) Statistical Packages for Social Sciences Version 24.0. SPSS Inc., Chicago, USA.

11. Duncan, D.B. (1955) Multiple range and multiple F-tests. Biometrics, 11(1): 1-42.

12. Hajati, H., Hassanabadi, A. and Yansari, A.T. (2012) Effect of Citrus Pulp on Performance and Some Blood Parameters of Broiler Chickens. $1^{\text {st }}$ International and $4^{\text {th }}$ National Congress on Recycling of Organic Waste in Agriculture.

13. Bahman, A.H., Alireza, T. and Siamak, A.R. (2011) Biochemical profile of chicken. Glob. Vet., 7(3): 238-241.

14. Akbarian, A., Golian, A., Gilani, H., Kermanshahi, H., Zhaleh, S., Akhavan, A., Smet, S.D. and Michiels, J. (2013) Effect of feeding citrus peel extracts on growth performance, serum components and intestinal morphology of broilers exposed to high ambient temperature during the finisher phase. Livest. Sci., 157(2-3): 490-497.

15. Abdel-Moneim, M.A., Hamady, G.A.A. and Motawe, H.F.A. (2014) The use of orange waste with and without enzymes in broilers' diets and its effect on their performance, carcass traits and some blood parameters. Res. J. Anim. Vet. Fish. Sci., 2(12): 14-19.

16. Abbasi, H., Seidavi, A., Liu, W. and Asadpour, L. (2015) Investigation on the effect of different levels of dried sweet orange (Citrus sinensis) pulp on performance, carcass characteristics and physiological and biochemical parameters in broiler chicken. Saudi J. Biol. Sci., 22(2): 139-146.

17. Ebrahimi, A., Qotbi, A.A.A., Seidavi, A., Edens, F.W., Laudadio, V. and Tufarelli, V. (2016) Selected plasma constituents of broiler chickens fed different levels of dried sweet orange (Citrus sinensis) peels. J. Anim. Plant Sci., 26(4): 949-955.

18. Dutta, S.K. and Hlasko, J. (1985) Dietary fibre in pancreatic disease: Effect of high fibre on fat malabsorption in pancreatic insufficiency and in vitro study of the interaction of dietary fibre with pancreatic enzymes. Am. J. Clin. Nutr., 41(3): 517-525.

19. Faiz, F., Khan, M.I., Sadiq, M. and Nawaz, H. (2017) Effects of dietary natural antioxidants from citrus waste on growth and blood antioxidants status of the broilers. Sarhad J. Agric., 33(3): 371-376.

20. Trovato, A., Monforte, M.T., Barbera, R., Rossitto., Galati, A.E.M. and Forestieri, A.M. (1996) Effects of fruit juices of Citrus sinensis L. and Citrus limon L. on experimental hypercholesterolemia in the rat. Phytomedicine, 2(3): 221-2267.

21. Parmar, H.S. and Kar, A. (2008) Antiperoxidative, antithyroidal, antihyperglycemic and cardioprotective role of Citrus sinensis peel extract in male mice. Phytother. Res., 22(6): 791-795. 